\title{
Bunocephalus erondinae, a new species of banjo catfish from southern Brazil (Siluriformes: Aspredinidae)
}

\begin{abstract}
Alexandre R. Cardoso
Bunocephalus erondinae, a new species of banjo catfish is described from the laguna dos Patos system, Rio Grande do Sul, Brazil. The new species differs from its congeners by the bony epiphyseal bar very wide ( $v s$. narrow). Bunocephalus erondinae is externally most similar to Bunocephalus doriae (rio Uruguay and rio Paraná-Paraguay basins), however, differs from this species by the following characters: the bony epiphyseal bar very wide ( $v s$. narrow); metapterygoid round, width is equal the height ( $v s$. metapterygoid elongate, width lesser than half of height), well developed lamina in the hypohyal and anterior ceratohyal bones ( $v s$. little developed or absent), 32 vertebrae ( $v s .34-35)$, first procurrent caudal-fin rays well developed ( $v s$. vestigial), vertebral parapophysis 5 distally expanded, shaped like an axe (vs. not expanded).

Bunocephalus erondinae, uma espécie nova de bagre banjo é descrita do sistema da laguna dos Patos, Rio Grande do Sul, Brasil. A espécie nova é distinguível de todas as espécies do gênero pela barra epifiseal óssea muito larga (vs. estreita). Bunocephalus erondinae é externamente muito similar a Bunocephalus doriae (bacias do rio Uruguai e rio Pananá-Paraguai), porém, difere desta espécie pelos seguintes caracteres: barra epifiseal óssea larga ( $v s$. estreita), metapterigoide arredondado, com largura igual a altura (vs. metapterigoide alongado, com largura menor que a metade da altura), lâmina bem desenvolvida no hipial e no cerato-hial anterior ( $v s$. pouco desenvolvida ou ausente), 32 vértebras (vs. 34-35), primeiros raios prócorrentes caudais bem desenvolvidos ( $v s$. vestigiais) da parapófise da quinta vértebra expandida na forma de um machado ( $v s$. não expandida).
\end{abstract}

Key words: Taxonomy, Bunocephalinae, Laguna dos Patos system, Rio Grande do Sul.

\section{Introduction}

Banjo catfishes are characterized by their body shape, which resembles the musical instrument known as banjo (Myers, 1960). Currently, the Aspredinidae possesses 13 valid genera (Acanthobunocephalus Friel, Amaralia Fowler, Aspredinichthys Bleeker, Aspredo Scopoli, Bunocephalus Kner, Dupouyichthys Schultz, Ernstichthys Fernández-Yépez, Hoplomyzon Myers, Micromyzon Friel \& Lundberg, Platystacus Bloch, Pseudobunocephalus Friel, Pterobunocephalus Fowler, and Xyliphius Eigenmann), all endemic from the Neotropical region. Bunocephalus is the most speciose genus in the family. Bunocephalus was proposed as a new genus by Kner (1855), but the type-species Platystacus verrucosus Bloch, 1794 was subsequently designated by Bleeker (1862-1863). Bunocephalus includes nine valid species distributed in the drainages of Magdalena, Orinoco, Amazonas, São Francisco, Paraná-Paraguay, Uruguay, laguna dos Patos, and in some rivers of the western slope of the Andes (Atrato, San Juan, and Patía) (Friel, 2003). Individuals of Bunocephalus species are usually found on submerged foliage or burried in the mud of rivers and backwater creeks.

In the present paper a new species of Bunocephalus from laguna dos Patos system, south Brazil is described.

\section{Material and Methods}

Measurements were taken point to point with a digital caliper in dorsal, ventral, and lateral view of specimens. Measurements are expressed as percents of standard length (SL), except subunits of head, expressed as percents of head length (HL). The measurements are: standard length (measured from snout tip to caudal-fin origin); head length (measured between snout tip and posterior tip of supraoccipital bone); predorsal length (measured between snout tip and dorsal-fin origin); length of unbranched dorsalfin ray (measured between its insertion and its distal tip);

Fundação Zoobotânica do Rio Grande do Sul, Museu de Ciências Naturais, Laboratório de Ictiologia. Rua Salvador França, 1427, $90690-000$ Porto Alegre, RS, Brazil. arcardoso.cardoso@gmail.com 
pectoral-fin spine length (measured between its insertion and its distal tip); length of unbranched pelvic-fin ray (measured between its insertion and its distal tip); length of uppermost unbranched caudal-fin ray (measured between its insertion and its distal tip); length of lowermost unbranched caudal-fin ray (measured between its insertion and its distal tip); abdominal length (measured between insertion of pectoral spine and insertion of unbranched pelvic-fin ray); post-abdominal length (measured from pelvic-fin insertions to anal-fin origin along ventral midline); cleithral width (measured between the lateralmost margins of contralateral cleithra); distance between coracoid processes (measured between distal tips of coracoid processes); length of coracoid process (measured between its origin and its distal tip); body depth at dorsal-fin origin (measured between dorsal-fin origin and ventral body surface); caudal-peduncle length (measured between insertion of first unbranched anal-fin ray and caudal-fin origin); caudal-peduncle depth (measured vertically from last unbranched anal-fin ray to dorsal body surface); caudalpeduncle width (measured as greatest horizontal peduncle width coequal with last unbranched anal-fin ray); anal-fin base length (measured between insertion of first unbranched anal-fin ray and insertion of last branched anal-fin ray); head depth (measured through a vertical between posterior margin of supraoccipital and ventral body surface); snout length (measuread between snout tip and lachrymal margin of orbit); interorbital width (measured between orbits dorsally); distance between anterior nostrils; distance between posterior nostrils; distance between maxillary barbels (measured between origins of maxillary barbels); distance between anterior mental barbels (measured between origins of anterior mental barbels); distance between posterior mental barbels (measured between origins of posterior mental barbels); and mouth width (measured at mouth gape). Counts are as followns: number of dorsal-fin rays; number of pectoral-fin rays; number of pelvic-fin rays; number of anal-fin rays, number of caudal-fin rays, and number of vertebrae. Vertebral counts include all vertebrae (including the first five vertebrae modified as the Weberian apparatus and complex vertebra). The compound caudal centrum (PU1+U1) was counted as one element following Lundberg $\&$ Baskin (1969). Anatomical descriptions and illustrations are made after dissection of cleared and stained specimens (c\&s) prepared according to the method of Taylor \& van Dyke (1985). Nomenclature of the bony structures follows de Pinna (1996). All morphological observations were made under a Zeiss SV8 microscope and anatomical illustrations were sketched using a camera lucida.

Institution abbreviations follow Ferraris (2007), plus institution: MCN, Museu de Ciências Naturais, Fundação Zoobotânica do Rio Grande do Sul, Porto Alegre; UFRGS, Departamento de Zoologia, Universidade Federal do Rio Grande do Sul, Porto Alegre, and UNT, Laboratório de Ictiologia Sistemática, Universidade Federal do Tocantins, Porto Nacional.

\section{Bunocephalus erondinae, new species} Fig. 1

Holotype. MCP 40877, 82.9 mm SL, Brazil, Rio Grande do Sul State, Pelotas, canal São Gonçalo, laguna dos Patos system

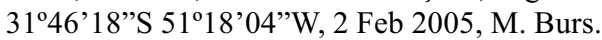

Paratypes. Brazil, Rio Grande do Sul State. MCP 40878, 17, 1 c\&s, 56.6-76.9 mm SL, collected with holotype; MCN 975, 1, $64.3 \mathrm{~mm}$ SL; MCN 976, 1, $60.2 \mathrm{~mm}$ SL; MCN 977, 1, $58.0 \mathrm{~mm}$ $\mathrm{SL}$, rio Pardo, arroio Jacaré, tributary of rio Pardo, 5 Aug 1961, A. A. Lise. MCN 899, 1, $63.7 \mathrm{~mm} \mathrm{SL}$; MCN 900, 1, $61.0 \mathrm{~mm}$ SL, Porto Alegre, lago Guaíba, 18 Aug 1963, L. Buckup. MCN 3666, 1, $54.9 \mathrm{~mm}$ SL, Montenegro, rio Caí, near farm Chaleira Preta, 18 Oct 1977, O. Kelsch. MCN 7079, 3, 49.4-64.2 mm SL, Porto Alegre, lago Guaíba at Parque Náutico, 3 May 1985, H. Grosser. MCN 9456, 1, $62.3 \mathrm{~mm}$ SL, Porto Alegre, lago Guaíba at Cais do Porto, 15 Jul 1985, H. Grosser. MCN 12183, 1, 51.7 mm SL, Triunfo, rio Jacuí at Porto de Belinha or Manga, 8 Sep 1994, K. M. Grosser, W. R. Koch \& R. Giacomini. MCN 14342, 5, 2 c\&s, 53.0-59.5 mm SL, Triunfo, rio Jacuí at Porto de Manga, 20 Oct 1994, K. M. Grosser \& F. S. Stobbe. MCP 8966, 1 c\&s, 71.6 mm SL, Taquara, rio dos Sinos, $29^{\circ} 41^{\prime} \mathrm{S} 50^{\circ} 46^{\prime} \mathrm{W}, 26$ Jan 1980, J. Casado. MCP 12030, 1, $58.5 \mathrm{~mm}$ SL, Porto Alegre, rio Jacuí at ilha do Pavão, Apr 1988, E. Malabarba. MCP 14515, 1, $56.9 \mathrm{~mm}$ SL, Porto Alegre, mouth of rio Jacuí, May 1988, E. R. Malabarba. MCP 14986, 1, $62.2 \mathrm{~mm}$ SL, Guaíba, rio Jacuí near the ilha do Lage, 14 Dec 1989, E. Malabarba \& A. Malabarba. MCP 15006, 1, 59.6 mm SL, Porto Alegre at rio Jacuí delta, 1991, E. R. Malabarba, A. Malabarba \& E. V. Malabarba. MCP 19079, 1 c\&s, $67.1 \mathrm{~mm} \mathrm{SL}$, Cristal, rio Camaquã at farm Corticeira, 3102'07'S 51 55 '50"W, 10 May 1996, J. F. P. da Silva. MCP 19486, 1, $60.6 \mathrm{~mm} \mathrm{SL}$, Triunfo, rio Taquari, 29 Oct 1996, M. Bruschi Jr. et al. MCP 33664, 7, 1 c\&s, 64.1-71.1 mm SL, Muçum, rio Taquari near mouth of rio Guaporé, 2910'10"S 51 53 '06"W, 5 Nov 2002, MCP team. MCP 33579, 1, $60.6 \mathrm{~mm}$ SL, Muçum, rio Taquari near mouth of rio Guaporé, 29 10 ' $10^{\prime \prime} \mathrm{S}$ $51^{\circ} 53^{\prime} 06^{\prime \prime} \mathrm{W}, 26$ Sep 2002, MCP team. MCP 38710, 2, 57.4$64.0 \mathrm{~mm} \mathrm{SL}$, Veranópolis, rio das Antas at channel of Monte Claro hydroelectric dam, 2901'02"S 51²8'37”W, May 2005, J. Litini, V. Cappati \& S. Rodrigues.

Diagnosis. Bunocephalus erondinae differs from its congeners by the bony epiphyseal bar very wide ( $v s$. narrow; Fig. 2). Also B. erondinae is distinguished from $B$. doriae by the tip of the vertebral parapophysis 5 expanded with the shape of an axe (vs. not expanded, Fig. 2), metapterygoid round, as the width is equal (vs. metapterygoid elongate, as the width lesser than half of height, Fig. 3), well developed lamina on hypohyal and on the anterior ceratohyal bones ( $v s$. little developed or absent, Fig. 4), first procurrent caudal-fin rays well developed (vs. vestigial, Fig. 5), and 32 vertebrae (vs. 3435); from $B$. aleuropsis by the absence of dark dots on the dorsal surface of the body (vs. present); from B. chaimaizelus by the maximum known standard length $83.1 \mathrm{~mm}$ SL (vs. 37 $\mathrm{mm} \mathrm{SL}$ ), and number of branched caudal-fin rays (7 vs. 8); from B. amaurus by the smaller interorbital width (24.1-29.2 vs. 32.2-32.4\% HL); from B. colombianus by the larger predorsal length (45.6-51.2 vs. 44.6-44.8\% SL); from $B$. 


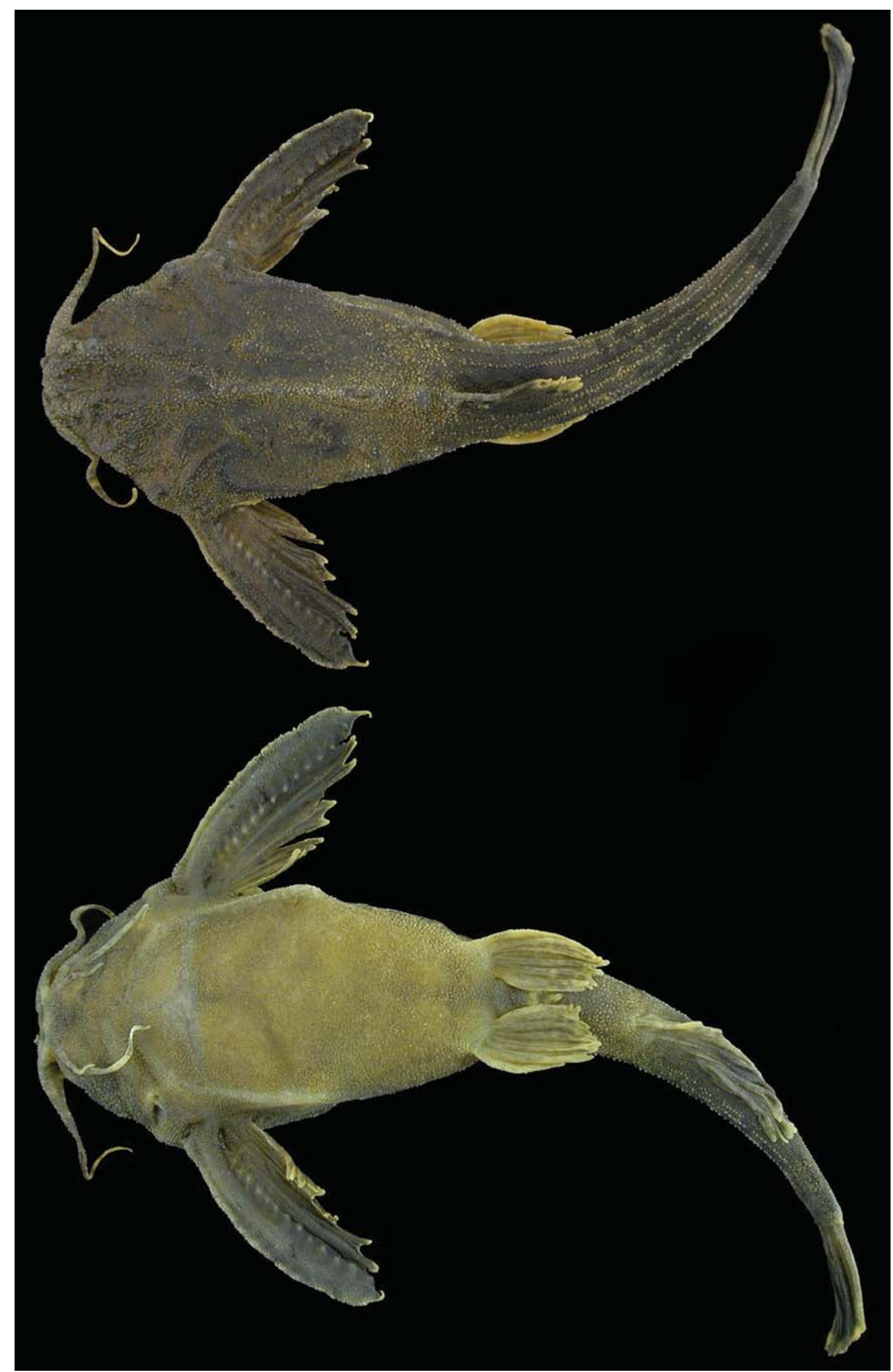

Fig. 1. Bunocephalus erondinae, MCP 40877, holotype, $82.9 \mathrm{~mm}$ SL, canal São Gonçalo, laguna dos Patos system, Pelotas, Rio Grande do Sul, Brazil. 
coracoideus by the interorbital width (24.1-29.2 vs. 29.3-37.8\% $\mathrm{HL}$ ), and distance between the mental barbels (23.0-30.2 vs. $18.2-22.9 \% \mathrm{HL}$ ); from $B$. knerii by having larger coracoid process (13.4-20.5 vs. 8.6\% HL), pectoral-fin spine length (24.732.7 vs. $24.3 \% \mathrm{SL}$ ), interorbital width (24.1-29.2 vs. $30.0 \% \mathrm{HL})$, and caudal-peduncle length (31.0-37.3 vs. $43.2 \% \mathrm{SL})$; from $B$. larai by the predorsal length (45.6-51.2 vs. 41.2-42.8\% SL), and length of coracoid process (13.4-20.5 vs. 9.2-10.1\% SL); and from $B$. verrucosus by the head length (21.2-25.2 vs. 25.4$27.8 \% \mathrm{SL}$ ), distance between the coracoid processes (19.7$27.3 v$ s. $15.4-19.3 \% \mathrm{SL}$ ), length of the coracoid process (13.410.5 vs. $22.3-24.6 \%$ SL), head depth (44.6-60.0 vs. 77.6-92.7\% $\mathrm{HL})$, and interorbital width (24.1-29.2 vs. 30.4-35.1\% HL).

Description. Morphometric data summarized in Table 1. Body shape, form and position of fins and barbels in Fig. 1. Anterodorsal profile of body with slight depression above orbits that continues faintly anteriorly between ridges formed by lateral margins of mesethmoid, and straight posteriorly until near to end of supraoccipital. Profile of skull convex and ornamented by three dorsomedial bony knobs (at the supraoccipital, dorsal lamina of Weberian apparatus and the middle nuchal plate). Skull ornamentation reduced compared with some aspredinids (e.g. Bunocephalus verrocusus). Posterodorsal profile of body straight from dorsal-fin origin to near base of caudal-fin, becoming slightly convex anteriorly to base of caudal-fin. Caudal peduncle slender, round in cross

Table 1. Morfometric data of holotype and paratypes $(\mathrm{n}=$ 55, including the holotype) for Bunocephalus erondinae. $\mathrm{SD}=$ Standard deviation.

\begin{tabular}{lcccc}
\hline & Holotype & Range & Mean & SD \\
\hline Standard length (mm) & 82.9 & $49.4-82.9$ & 64.3 & - \\
& Percents of standard length & & & \\
Head length & 23.0 & $21.2-25.2$ & 23.5 & 0.8 \\
Predorsal length & 48.0 & $44.4-51.2$ & 48.4 & 1.3 \\
Length unbranched dorsal-fin ray & 12.9 & $12.1-18.3$ & 15.4 & 1.3 \\
Pectoral spine length & 29.8 & $24.7-32.7$ & 28.4 & 1.9 \\
Length of unbranched pelvic-fin ray & 11.9 & $10.3-15.6$ & 12.2 & 1.2 \\
Length of upper unbranched caudal-fin ray & 19.8 & $15.7-24.1$ & 20.6 & 2.0 \\
Length of lower unbranched caudal-fin ray & 18.2 & $15.5-23.0$ & 19.6 & 1.6 \\
Thoracic length & 33.5 & $28.5-37.2$ & 32.6 & 2.0 \\
Abdominal length & 17.9 & $12.8-21.8$ & 18.5 & 1.6 \\
Cleithral width & 31.4 & $29.4-33.9$ & 31.4 & 1.2 \\
Distance between coracoids & 25.1 & $19.7-27.3$ & 23.1 & 1.8 \\
Length of coracoid bone & 20.0 & $13.4-20.5$ & 16.9 & 1.6 \\
Body depth at dorsal-fin origin & 18.5 & $8.8-15.9$ & 12.4 & 1.4 \\
Caudal-peduncle & 33.8 & $31.0-38.6$ & 34.4 & 1.6 \\
Caudal-peduncle depth & 4.8 & $3.6-5.3$ & 4.3 & 0.3 \\
Caudal-peduncle width & 4.9 & $3.0-5.4$ & 4.5 & 0.5 \\
Anal-fin base length & 21.2 & $16.1-23.6$ & 19.8 & 1.6 \\
& \multicolumn{1}{c}{ Percents of head length } & & & \\
Head depth & 44.6 & $44.6-60.0$ & 54.2 & 3.7 \\
Snout length & 27.4 & $20.5-30.4$ & 25.8 & 1.9 \\
Interobital width & 26.7 & $24.1-29.2$ & 27.0 & 1.1 \\
Distance between anterior nostrils & 17.7 & $14.0-19.9$ & 17.2 & 1.3 \\
Distance between posterior nostrils & 29.6 & $24.5-35.0$ & 29.2 & 2.3 \\
Distance between maxilary barbels & 29.1 & $29.1-42.1$ & 34.3 & 2.8 \\
Distance between anterior mental barbels & 28.8 & $20.2-33.9$ & 27.3 & 2.2 \\
Distance between posterior mental barbels & 53.1 & $39.6-54.3$ & 47.4 & 3.1 \\
Mouth width & 37.9 & $27.0-43.0$ & 35.6 & 3.4 \\
\hline & & & &
\end{tabular}

section, tapering to caudal-fin. Ventral body profile slightly convex from mouth to insertion of pelvic-fin; straight from end of pelvic-fin base to insertion of anal-fin; profile from anal-fin origin to base of caudal-fin slightly concave, becoming slightly convex at base of caudal-fin.

Head wide and depressed. Eyes small and positioned approximately laterally. Skin covering eye dense and pale. Anterior nostrils covered, located at tip of snout, projecting beyond upper lip. Posterior nostrils without flap, opening anteromedially to eye. Mouth subterminal, jaws and lips unequal; upper lip more
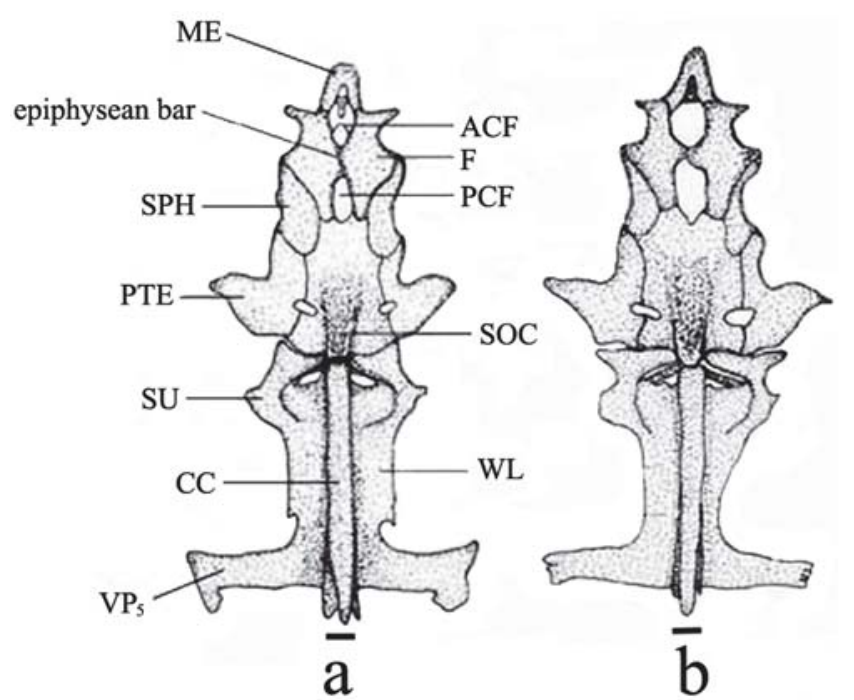

Fig. 2. Dorsal view of neurocranium and Weberian complex of (a) Bunocephalus erondinae, paratype, MCP 8966 (71.6 mm SL) and of (b) B. doriae, MCP 13176 (50.9 mm SL). ACF, anterior cranial fontanel; $\mathrm{CC}$, complex centrum; F, frontal; $\mathrm{ME}$, mesethmoid; PCF, posterior cranial fontanel; PTE, pterotic; SOC, supraoccipital; $\mathrm{SPH}$, sphenotic; $\mathrm{SU}$, supracleithrum; $\mathrm{VP}_{5}$, ventral parapophysis 5 ; and WL, Weberian lamina. Scale bar $=1 \mathrm{~mm}$.
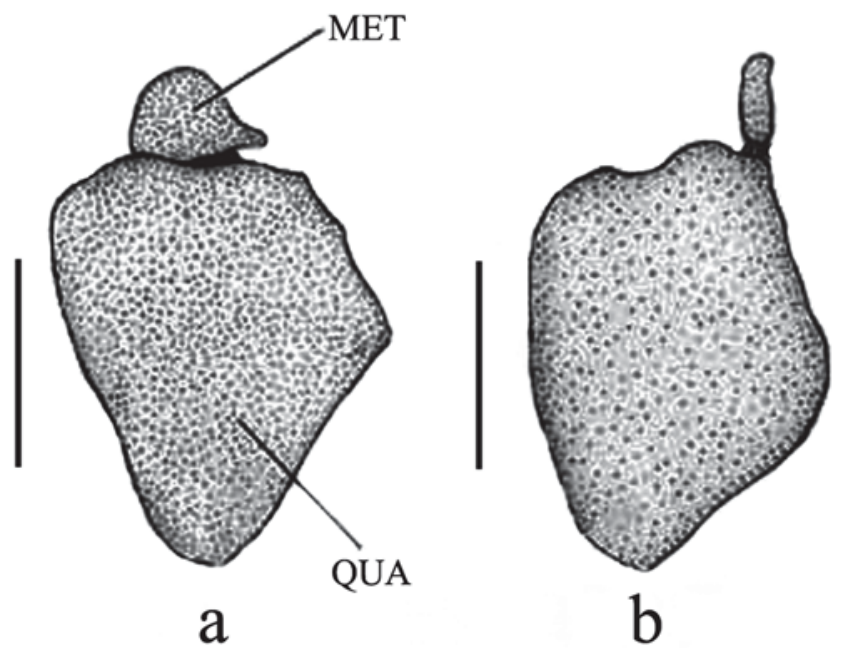

Fig. 3. Dorsal view of the quadrate and metaperygoid of (a) Bunocephalus erondinae, paratype, MCP 33664 (68.5 mm SL) and of (b) B. doriae, MCP 13176 (50.9 mm SL). MET, metapterygoid, and QUA, quadrate. Scale bar $=1 \mathrm{~mm}$. 
prominent relative to lower lip. All barbels simple, unbranched; maxillary barbel reaching slightly last pectoral-fin spine insertion; posterolateral mental barbel twice as long as anteromedial barbel. Opercular opening reduced to small valvular slit just anterior to pectoral-fin spine insertion.
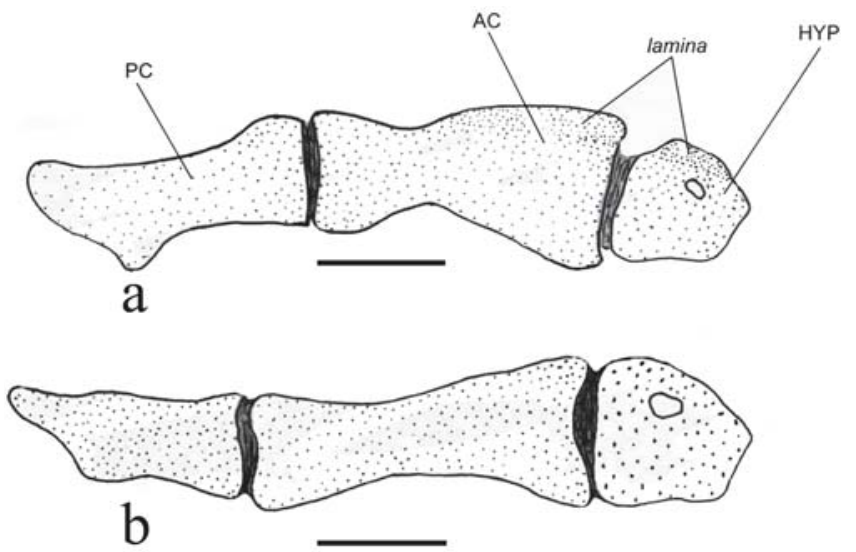

Fig. 4. Dorsal view of the hyoid bar of (a) Bunocephalus erondinae, paratype, MCP 33664 (68.5 mm SL) and of (b) $B$. doriae, MCP 13176 (50.9 mm SL). AC, anterior ceratohyal; HYP, hypohyal; and PC, posterior ceratohyal. Scale bar $=1 \mathrm{~mm}$.

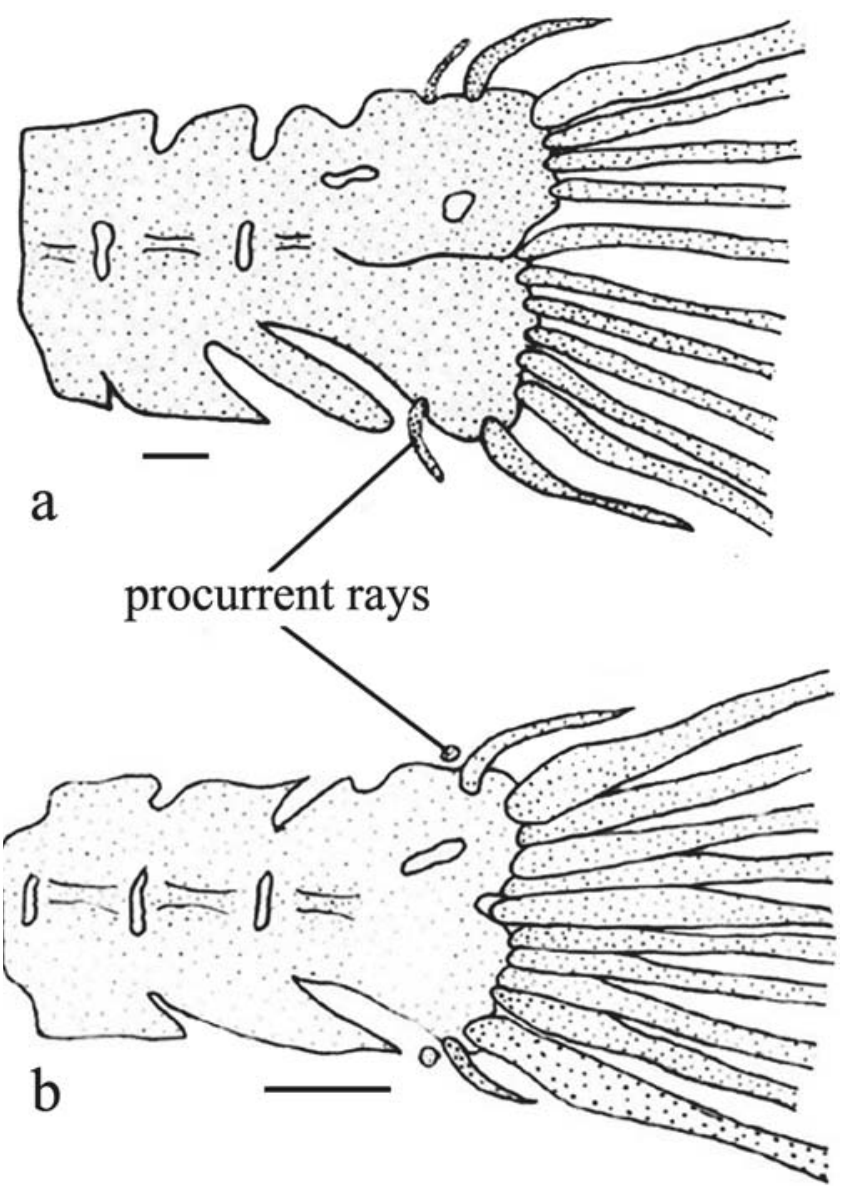

Fig. 5. Lateral view of the caudal skeleton of (a) Bunocephalus erondinae, paratype, MCP 33664 (68.5 mm SL) and of (b) $B$. doriae, MCP 13176 (50.9 $\mathrm{mm} \mathrm{SL})$. Scale bar $=1 \mathrm{~mm}$.
Dorsal-fin rays i,4. Dorsal-fin spinelet absent. Last dorsalfin ray not adnate to body, membrane between last dorsalfin ray and body small. Pectoral-fin rays I,5. Pelvic-fin rays $\mathrm{i}, 5$, fourth ray longest but not reaching anal-fin origin; pelvic splint absent. Adipose fin absent. Anal-fin rays ii,5-ii,7, membrane between last anal-fin ray and body small. Caudalfin rays i,8,i; rounded. Caudal-fin unbranched rays shorter than branched rays; two procurrent rays on upper and lower lobe, respectively. Lateral-line canal complete but rarely reaching caudal-fin origin. Total vertebrae 32 .

Color in alcohol. Head light brown; body with three dark brown saddles on a light brown base; first saddle at dorsalfin, and two saddles on posterior body, saddles may fuse and expand ventrally and laterally to give appearance of light brown dorsal patches on dark brown base; anterior ventral surface much lighter than dorsal surface; pectoral-fin brown with light distal margin; ventral and anal fins whitish with dark blotches; and dorsal and caudal-fins dark gray with light distal margin. All barbels brown with dark blotches.

Distribution. Known from several tributaries to the laguna dos Patos system, Rio Grande do Sul, Brazil (Fig. 6).

Etymology. The specific name, erondinae, is given in memory to my mother Erondina Rodrigues Cardoso.

\section{Discussion}

Of the valid species of Bunocephalus (Friel, 2003), that remained after Friel's (2008) description of Pseudobunocephalus, only B. larai and B. doriae occurs in southern Brazil. Bunocephalus larai is distinguished from $B$. doriae and $B$. erondinae by the absence of the bony epiphyseal bar formed by the frontals (vs. presence). Bunocephalus doriae was described by Boulenger (1902), whose type-locality is Villa Rica, Paraguay, and Posadas rio Paraná, Argentina. Forty years after the description of $B$. doriae, Eigenmann \& Allen (1942) described Bunocephalus retropinnis, with syntypes from Cacequi, Rio Grande do Sul, Brazil. They distinguished B. retropinnis from all other species by the posterior position of the dorsal-fin, with the origin is closer to caudal-fin than snout. Mees $(1988,1989)$ recognized B. retropinnis as Dysichthys doriae (=Bunocephalus doriae). I examined one specimen of $B$. doriae from the Cacequi region, type-locality of $B$. retropinnis, collected in a small tributary to the rio Santa Maria, rio Ibicuí drainage, Rosário do Sul, RS, and some additional specimens from this drainage. I found no differences between these specimens and all other specimens from the rio Uruguay drainage, indicating that $B$. retropinnis should indeed be a synonym of $B$. doriae, corroborating Mees (1988 and 1989)'s conclusions.

Mees (1989) and Friel (1994) identified two specimens in alcohol (MZUSP 25155, 2, 71.0-71.5 mm SL) from rio Paranhana, tributary to the rio Sinos (laguna dos Patos system) near Taquara, Rio Grande do Sul, as B. doriae. I 


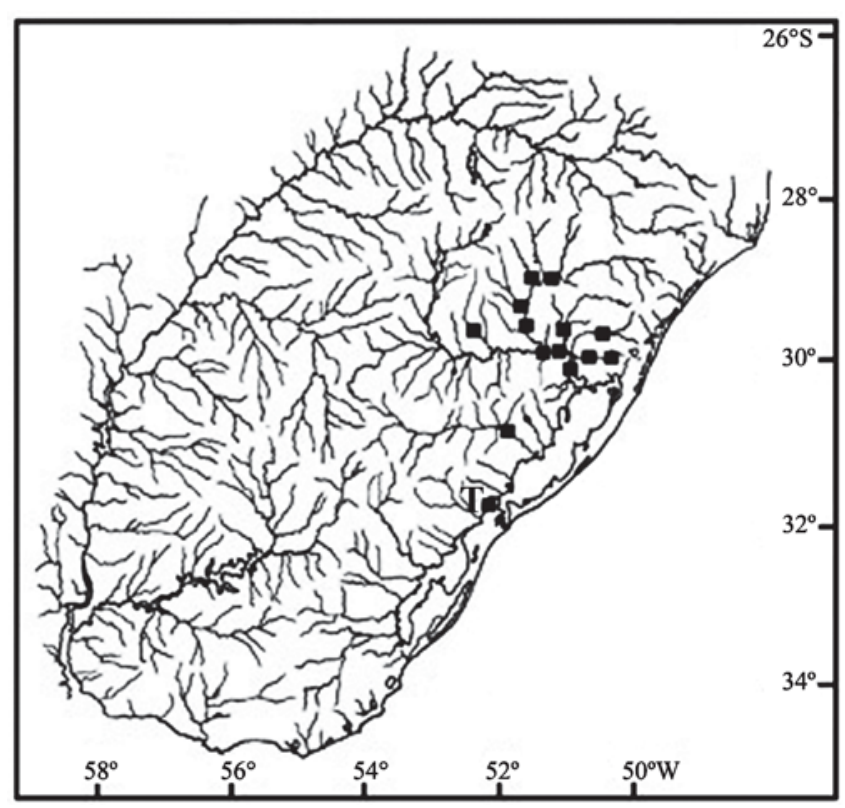

Fig. 6. Map of Rio Grande do Sul, Brazil, and Uruguay showing the distribution of Bunocephalus erondinae. Each square represents one or more collecting localities. "T" indicates the type-locality.

examined several specimens in alcohol, and some stained and cleared specimens of $B$. doriae from the rio Uruguay drainage (upper, middle and lower portions), as well as specimens from the rio Paraná-Paraguay drainage, and material from the laguna dos Patos system deposited at MCP and MCN, and I concluded through osteological characters that the specimens from the laguna dos Patos system represent a new species, herein described as B. erondinae.

Comparative material. Bunocephalus aleuropsis: Brazil, Mato Grosso State: MCP 34142, 2, 36.3-37.4 mm SL, Ribeirão Cascalheira, rio São João. Acre State: MCP 35744, 1, $46.3 \mathrm{~mm}$ SL, Bujari, rio riozinho do Andirá. Tocantins State: UNT 2038, 1, 45.3 mm SL, Ipueiras, rio Tocantins; UNT 2039, $1 \mathrm{c \& s,} 66.8 \mathrm{~mm} \mathrm{SL}$, Porto Nacional, rio Tocantins; UNT 2040, 1, $64.6 \mathrm{~mm}$ SL, Peixe, rio Santa Tereza; UNT 2041, 1, 60.5 mm SL, Palmas, ribeirão Tucum; UNT 2042, 1, $72.8 \mathrm{~mm}$ SL, Ipueiras, rio Formiga; UNT 2333, 1, Porto Nacional, rio Tocantins. Bunocephalus amaurus: Guyana: FMNH 53121, holotype, $55.8 \mathrm{~mm}$ SL, Konavaruk. Bunocephalus amaurus aloikae: French Guiana: ZMA 102.229, holotype, $62.5 \mathrm{~mm} \mathrm{SL}$, rio Litany near Aloiké village. Bunocephalus amaurus sipaliwini: Suriname: ZMA 102.228, holotype, $70.6 \mathrm{~mm} \mathrm{SL}$, rio Sipaliwini, bordering Paru Savannah. Bunocephalus chaimazelus: Guyana: FMNH 53122, x-rayed, holotype, $26.7 \mathrm{~mm} \mathrm{SL}$, Erukin; FMNH 53123, 1 of 2 paratypes, $35.2 \mathrm{~mm} \mathrm{SL}$, Erukin; FMNH 53125, 2, paratypes, 22.3-28.1 mm SL, Gluck Island; FMNH 7370, 1, paratype, $23.3 \mathrm{~mm}$ SL, Tumatumari, lower rio Potaro. Bunocephalus colombianus: Colombia: Choco: FMNH 56038, x-rayed, holotype; $71.2 \mathrm{~mm}$ SL, Raspadura; CAS 35249, paraype, $84.7 \mathrm{~mm}$ SL, Quibdo, rio Quito into río Atrato (río Atrato basin); FMNH 56668, paratype, 112.7 mm SL, Raspadura. Bunocephalus coracoideus: Brazil, Pará State: MNHG 255.032, 6 of 10, 70.6-84.0 mm SL, igarapé Cuxiu, near aval d'Óurem; MHNG 2551.015, 1, 82.9 mm SL, rio Tocantins, ca. $3 \mathrm{~km}$ of São Felix. Tocantins State: MHNG 2609.034, 1, 35.9 mm SL, Dégrade Florian Saut Genipa; MHNG 2617.011, 2,1 c\&s, 34.1-57.1 mm SL, Sinnamary. Peru: Loreto: ANSP 138984, 2, 1 c\&s, 49.2-80.0 mm SL, Vinicity Iquitos, río Nanay. Bunocephalus doriae: Brazil: Rio Grande do Sul State: MCP 9336, 1, $30.0 \mathrm{~mm} \mathrm{SL}$, Alegrete, in the road for Alegrete; MCP 13176, 7, $1 \mathrm{c \& s}, 36.0-50.9$ mm SL, São Nicolau, rio Uruguay; MCP 13241, 1, 61.7 mm SL, Porto Xavier, rio Comandaí, in the road Porto Xavier/Porto Lucena; MCP 13327, 1, 40.2 mm SL, Roque Gonzáles, MCP 13466, 1, 47.0 $\mathrm{mm}$ SL, São Borja, rio Uruguay, in the locality of Guarruchos; MCP 14267, 5, 1 c\&s, 61.5-73.2 mm SL, Bagé, rio Negro, in the road between Bagé/Aceguá; MCP 15037, 1, 35.7 mm SL, Pirapó, arroio Barreiro, in the locality of Barreiro; MCP 16241, 3 of 10, 64.6-69.1 $\mathrm{mm}$ SL, Bagé, rio Negro, $c a .14$ km of Bagé towards Aceguá; MCP $21657,3,32.5-45.3 \mathrm{~mm}$ SL, Uruguaiana, rio Uruguay and lateral puddles in the beach of the Formosa, near of São Marcos; MCP 23155, 8, 1 c\&s, 47.8-81.3 mm SL, São Francisco de Assis, rio Inhacunda; MCP 26828, 1, 48.1 mm SL, Rosário do Sul, sanga da Areia in RS 640, tributary of the rio Santa Maria; MCP 27660, 1, $31.7 \mathrm{~mm}$ SL, Jaguari, arroio Caracol, in the road BR 453; MHNG 2527.064, 2, 72.1-74.1 mm SL, Bagé, rio Negro, road Bagé-Aceguá. Santa Catarina State: MCP 13359, 1, 33.8 mm SL, Itá, rio Uruguay. Mato Grosso State: MCP 20879, 1, $61.3 \mathrm{~mm} \mathrm{SL}$, Riqueza, rio Iracema; MCP 35747, 1 c\&s, 60.5 mm SL, Mirasol d'Oeste, riacho tributary of the rio Caeté, tributary of the rio Juaru, in the BR-174, ca. $72 \mathrm{~km} \mathrm{NW}$ of the rio Paraguay; MCP 35752, 1, $29.2 \mathrm{~mm} \mathrm{SL}$, Poconé, in the road Mato Grosso (MT-060), towards Poconé. Paraguay: MHNG 2159.044, 2 of 4, $1 \mathrm{c} \& s, 41.4-60.6 \mathrm{~mm}$ SL, Itapua, ao Poromoco, San Benito (Pastoreo); MHNG 2226.042, 2, 61.8-72.2 mm SL, Paraguari, Cabellero, ao Paso Ybucu; MHNG 2226.043, 2, 63.2-66.6 mm SL, Cordilheira, creek $10 \mathrm{~km}$ South of Tobati. Bunocephalus knerii: Equador: NMW-10976, 1 syntype, 50.7 mm SL, Canelos; FMNH 99481, 1, 50.7 mm SL, Napo, Capihuara, tributary of rio Payamino. Bunocephalus larai: Brazil: Minas Gerais State: MCP 28376, 2, 48.6-53.9 mm SL, rio Paranaíba, córrego tributary of the rio Paranaíba; MCP 28377, 2, 1 c\&s, 51.1$55.6 \mathrm{~mm}$ SL, rio Paranaíba, ribeirão de Fora, road rio Paranaíba/ Serra do Salitre. Mato Grosso State: MZUSP 22614, 2, 36.0-37.9 $\mathrm{mm}$ SL, rio Paraná in front of Jupiá. São Paulo State: MZUSP 23092, 7, 26.0-31.3 mm SL, rio Paraná, in the ilha da Solteira. Bunocephalus verrucosus: Brazil: Amazonas: MCP 29811, 1, 98.4 mm SL, Tefé, lago Tefé, in the community Tefé; MCP 29812, 1, $77.8 \mathrm{~mm}$ SL, Tefé, lago Tefé; MCP 35743, 4, 1 c\&s, 55.8-82.7 mm SL, Bujari, igarapé Maninguari in the BR-364 (riozinho Andirá drainage). Guiana: MHNG 2281.52, 1, $92.7 \mathrm{~mm} \mathrm{SL}$, Annai, afluent of río Rupununi, North Rupununi. Peru: MHNG 2395.58, 2, 27.129.7 mm SL, Ucayali, afluent of río Jcayali (Tachsitea).

\section{Acknowledgements}

I am grateful to Sonia Fisch-Muller (MHNG), Isaäc Isbrücker (ZMA), Ernst Mikschi (NMW), Luiz Malabarba (UFRGS), Marco A. Azevedo (MCN), Paulo Lucinda (UNT), and Thomas Litz (Grupo de Interes Fauny y Flora dulceacuicola-Montevideo) for loan of specimens. I owe special thanks to Paulo Lucinda, Roberto Reis (MCP) and Vinicius Bertaco (UFRGS) for comments and suggestions on the manuscript. My special thanks to Sonia Fisch-Muller and Claude Weber for lodging at the Museum d'Histoire Naturelle, where I examined a great portion of the aspredinid specimens cited in this work and my Ph.D. study. Also, my special thanks to John P. Friel and his wife for lodging in a visit to the Cornell University Museum of 
Vertebrates, Ithaca. This research was partially supported by the Conselho Nacional de Desenvolvimento Científico e Tecnológico (CNPq). Fieldwork was supported by the All Catfish Species Inventory (NSF DEB-0315963).

\section{Literature Cited}

Bleeker, P. 1858. De visschen van den Indischen Archipel. Beschreven en toegelicht. Siluri. Verhandelinger der Koninklijke Natuurkunbige Vereeniging in Nederlandsch Indë. Acta Societatis Regiae Scientiarum Indo-Neerlandicae, 4(1-12): 370p.

Bleeker, P. 1862-1863. Atlas Ichthyologique des Indes Orientales Néêrlandaises, Publié sous les Auspices du Gouvernement Colonial Néêrlandais. Tome II. Siluroides, Characoides et Hétérobranchoides, Amsterdam, 112p.

Bloch, M. E. 1794. Naturgeschichte der auständischen Fische. 4(8): 1-174.

Boulenger, G. A. 1902. Description of new fishes and reptiles discovered by D. F. Silvestri in South America. Annals and Magazine Natural History, 9(52): 284-288.

Eigenmann, C. H. 1912. Some results from an ichthyologic reconnaissance of Colombia, South America. Indiana University Studies, 16: 1-27.

Eigenmann, C. H. \& W. R. Allen. 1942. Fishes of western South America. I. - The intercordilleiran and Amazonian lowlands of Peru. II. The high pampas of Peru, Bolivia, and northern Chile. With a revision of the Peruvian Gymnotidae, and of the genus Orestias. University of Kentucky, 5: 1-494.

Fernández-Yépez, A. 1953. Algumas notas sobre los peces Asprediformes con descripción de Ernstichthys anduzei, nuevo e interesante bunocephalido. Novedades Cientificas, Contribuciones ocasionales del Museo de Historia Natural La Salle, 11: 1-6.

Fowler, H. W. 1943. Zoological results of the second Bolivian expedition for the Academy of Natural Sciences of Philadelphia, 1936-1937. Part II. - Additional new fishes. Notulae Naturae, Philadelphia, 120: 1-7.

Fowler, H. W. 1954. Os peixes de água doce do Brasil. $4^{\mathrm{a}}$ entrega. Arquivos de Zoologia do Estado de São Paulo, 9: 1-400.

Friel, J. P. 1994. A phylogenetic study of the Neotropical banjo catfishes (Teleostei: Siluriformes: Aspredinidae). Unpublished Ph.D. Dissertation, Duke University, Durham, NC, 256p.

Friel, J. P. 1995. Acanthobunocephalus nicoi, a new genus and species of miniature banjo catfish from the upper Orinoco and Casiquiare Rivers, Venezuela. (Siluriformes: Aspredinidae). Ichthyological Exploration of Freshwaters, 6(1): 89-95.
Friel, J. P. 2003. Family Aspredinidae. Pp. 261-267. In: R. E. Reis, S. O. Kullander \& C. J. Ferraris Jr. (Eds.). Check List of the Freshwater Fishes of South and Central America. Porto Alegre, Edipucrs, 729p.

Friel, J. P. 2008. Pseudobunocephalus, a new genus of banjo catfish with the description of a new species from Orinoco River system of Colombia and Venezuela (Siluriformes: Aspredinidae). Ichthyological Exploration of Freshwaters, 6(3): 293-300.

Friel, J. P. \& J. G. Lundberg. 1996. Micromyzon akamai, gen. sp. nov., a small and eyeless banjo catfish (Siluriformes: Aspredinidae) from the river channels of the lower amazon basin, Copeia, 1996(3): 641-648.

Kner, R. 1855. Ichthyologische Beiträge. I. Über die gattungen Aspredo und Chaca C. V. aus der famile der welse (Siluroidei). Sitzungsberichte der Mathematich-Naturwisswinschaftlichen Classe der Kaiserlichen Akademie der Wissenschaften, 8: 92-105.

Lundberg, J. G. \& J. N. Baskin. 1969. The caudal skeleton of the catfishes, Order Siluriformes. American Museum Novitates, 2398: 1-49.

Mees, G. F. 1988. The genera of the subfamily Bunocephalinae (Pisces, Nematognathi, Aspredinadae). Proceedings of the Koninklijke Nederlandse Akademie van Wetenschappen, 91(1): 85-102.

Mees, G. F. 1989. Notes of the genus Dysichthys, subfamily Bunocephalinae, family Aspredinidae (Pisces, Nematognathi). Proceedings of the Koninklijke Nederlandse Akademie van Wetenschappen, 92(2): 189-250.

Myers, G. S. 1942. Studies on South American fresh-water fishes I. Stanford Ichthyological Bulletin, 2(4): 89-114.

Myers, G. S. 1960. The genera and ecological geography of the South American banjo catfishes, family Aspredinidae. Stanford Ichthyological Bulletin, 7(4): 132-139.

de Pinna, M. C. C. 1996. A phylogenetic analysis of the Asian catfish families Sisoridae, Akysidae, and Amblypidae, with hypothesis on the relationships of the Neotropical Aspredinidae (Teleostei, Ostariophysi). Fieldiana, Zoology, 84: 1-83.

Schultz, L. P. 1944. The catfishes of Venezuela, with description of thirty-eighth new forms. Proceedings of the United States National Museum, 94(3172): 173-338.

Scopoli, G. A. 1777. Introductio ad historiam naturalem, sistens genera lapidum, plantarum et animalium hactenus detecta, caracteribus essentialibus donata, in tribus divisa, subinde ad leges naturae. Pragae. Introductio ad Historiam Naturalem, 10: 3-506.

Taylor, W. R. \& G. C. van Dyke, 1985. Revised procedures for staining and clearing small fishes and other vertebrates for bone and cartilage study. Cybium, 9(2): 107-119.

Accepted March 31, 2010 Published September 24, 2010 